\title{
Belgeo
}

Revue belge de géographie

\section{A practice-based approach to the conceptualisation of geographical mobility}

Conceptualisation de la mobilité géographique: une approche par les pratiques

\section{Mathis Stock and Philippe Duhamel}

\section{(2) OpenEdition}

12 Journals

\section{Electronic version}

URL: http://journals.openedition.org/belgeo/12415

DOI: $10.4000 /$ belgeo. 12415

ISSN: 2294-9135

Publisher:

National Committee of Geography of Belgium, Société Royale Belge de Géographie

\section{Printed version}

Date of publication: 30 June 2005

Number of pages: $59-68$

ISSN: 1377-2368

\section{Electronic reference}

Mathis Stock and Philippe Duhamel, "A practice-based approach to the conceptualisation of geographical mobility", Belgeo [Online], 1-2 | 2005, Online since 27 October 2014, connection on 05 February 2021. URL: http://journals.openedition.org/belgeo/12415 ; DOI: https://doi.org/10.4000/ belgeo. 12415

This text was automatically generated on 5 February 2021.

Belgeo est mis à disposition selon les termes de la licence Creative Commons Attribution 4.0 International. 


\title{
A practice-based approach to the conceptualisation of geographical mobility
}

Conceptualisation de la mobilité géographique: une approche par les pratiques

\author{
Mathis Stock and Philippe Duhamel
}

The authors would like to thank Tania Lines, Home of geography, Rome for helping to establish a better English than that of a first draft, and an anonymous referee for useful comments on an earlier version of the text.

\section{Mobility as a geographical problem}

1 One main aspect of the geographical context of human societies is the increased mobility of persons, goods and information. Tourism, leisure, business, residence, migrations etc. are fields of this mobility. Nowadays, the figures allow us to illustrate this fact on numerous spatial scales: in France, 6.4 million business trips were taken in 2002, 28 percent of which abroad; there were 715 million "international tourists" in 2002 throughout the world; 35 million tourists in Las Vegas in 2001; 75 million border crossings in France in 2002, etc.

2 Although mobility is recognized as an important field of geographical investigation, its implications have not yet been clarified. Often, mobility is seen as flow of persons, goods and information (Bassand et al., 1985), but one sees mobility as "taken-forgranted". We are not surprised when facing mobility, but we should be; then we would see that mobility arises in a certain context, that geographers have approached places and spaces as if there were no mobility and that there could be conceptual difficulties when dealing with mobility. Indeed, mobility raises several problems for the geographical investigation of place.

3 Fundamentally, mobility affects places in the sense that exchanges take place in and relate to a great number of places. However, it is interesting to observe that places are 
increasingly concerned with mobility. It is Helmfrid (1968), who understood this remarkably well. In his study of mobility in Sweden, he underlines the significance of places. Firstly, he sees that the maps of settlements only take into account, in the best of cases, the "overnight population". Secondly, he sees that "In delimiting a small section of a country, these days we can no longer grasp the meaning of a specific population group, in delimiting a specific population group, we no longer grasp the meaning of a particular terrestrial surface" (Helmfrid, 1968, p. 450). Finally, he sees that "The increase in mobility and the movements of humans leads to a decrease in the significance of traditional static spatial structures. We can focus on this by using the example of the population map. These days, the traditional population map does not show the true spatial distribution of people, not even the average situation, but merely indicates where people are legally registered following the Census. In observing the flow of movements, one can see three patterns of spatial distribution of the population which are recurrent and relatively stable, each of which should have their own "population map" (p.446). This concerns the time distribution of the "overnight population", the working population and the leisure and holiday population.

Another problem for geographical studies is the presence of people other than registered residents. Often, the question of a dwelling is raised only for its residents, and their socio-economic-demographic characteristics that define a place; but, fundamentally, the quality and/or identity of place is also defined by those who do not reside there. Two types of places could be genuinely referred to as a "place of mobility": towns/cities and tourist places. Indeed, research on cities or urban places acknowledges their function as market places (Bairoch, 1985) and, in a more sophisticated sense, defines cities as places "which maximise face-to-face interactions" (Claval, 1981; Lévy, 1994). This means the necessity for the presence of non-residents. In the same vein, tourist places are fundamentally places where "strangers" encounter locals. Often, the opposition between "insider" and "outsider" is drawn in order to acknowledge that difference. However, it also seems that the presence of tourists in a tourist place is legitimate: through the acceptation of the local population - the supply of hotels, bed \& breakfasts, tourist offices, signs, tour guides, etc.

5 These two problems lead to a major issue for contemporary geography: to identify, in studies on particular or generic places, the presence of permanent and temporary inhabitants. Indeed, from the point of view of a place, generalized mobility leads to two modalities: the departure of residents and the arrival of substitute residents.

Thus, the issue of mobility is not only a scientific problem, but also an ethical and political problem: what are the rights and duties of non-residents? To what extent should non-residents contribute to local costs? In Europe, the development of urban "time politics" is another attempt to solve the problem of the presence of nonresidents. However, there is also the other side of the coin to be considered: individuals are mobile, their presence in their place of residence is not constant. They may work in other places, go on holiday or take business trips. They are "temporary inhabitants" of their home place (Stock, 2001).

\section{Searching for the adequate words for mobility}

7 Nevertheless, what does "mobility" mean? How can we adopt an adequate approach towards this phenomenon? First of all, different definitions are possible: mobility as a 
flow, as a "practice" (Juan et al., 1997) and as a "system" (Bassand et al., 1985). From the point of view of the individual, mobility can be regarded as the expression of the localization of practices in a place other than that of residence. The move from one place to another is an interesting topic of analysis: some of these itineraries concern familiar places, everyday places; others imply a transfer, a move from the home place to unfamiliar places.

8 In which terms can mobility be referred to? We could suggest six words for it: movement, migration, mobility, circulation, transport and transfer (déplacement). How can these terms be distinguished?

9 First of all, we will begin with "migration" and "circulation" (Zelinsky, 1971). "Migration" could be defined as a change in the place of residence, where the centre of gravity of the activity space changes (Courgeau, 1988). The research approaches different spatial scales of migration: international migration, interregional migration, migration from rural areas to urban places, and so on. However, this also implies the definition of a temporal scale: usually, the year is the basis of these changes, be it in statistics or in research. Thus, the practice of owning a second home is not to be considered migration, because the temporal scale is often a weekly or monthly one. The temporal scale of a year also means that migration is an exceptional change in place, a break in the routine of everyday life. The change in place implies the encounter and confrontation with a new, often strange place, which has to be transformed into a familiar place. This is the most difficult achievement for migrants moving from one country to another. One of the technologies of the appropriation of places are in this context networks of immigrants and the creation of clusters in metropolises. Fundamentally, migration implies a change in dwelling.

10 "Circulation" does not necessarily imply a departure from the place of residence, but expresses a temporary practice of movement to places on different temporal scales. The place of residence does not change and the recursive practices take place in the space-time of everyday life. Regularity is a pattern of commuting, but also of numerous leisure practices. Often, the local or regional scale suffices for these kinds of practices, although high-speed modes of transport allow an extension of the number of places accessible in a day. Indeed, for a Londoner, it is now possible to go for a day's skiing in the Alps or to go clubbing in Ibiza; Parisians can spend a night on the town in Dublin; Israelis have the possibility of going shopping for a day in London, and so on. Circulation also determines the practices adopted outside the norms of everyday life, tourism being a perfect example. This results in a temporary absence from the place of residence for other unfamiliar places. However, the temporary nature of this practice, which entails a return to the place of residence, distinguishes it from migration. Indeed, it does not question integration into (local, national) society and circulation occurs with regard to the place of residence, where everyday life is carried out.

11 "Transport" and "transfer" (déplacement) do not define forms of movement, but the conditions in which these movements are carried out. Some movements entail the transfer of a person, others a simple trip from one point to another. Transfer signifies that movements are made to "other places", where people go beyond a "horizon of alterity" (Lazzarotti, 2001), where places are fundamentally different. These are unfamiliar places, where individuals discover the specific sense of place: a break from everyday, familiar places. It is a definitive break in the case of migrants or a temporary one in the case of tourism or business trips. "Transport" is limited to a simple 
movement without involving a break with everyday life - even in the case of great distances. A certain routine is established in which the individual does not raise the questions of when and how. This is expressed in the perfect knowledge of the technologies of movement, such as train or flight timetables, but where reflexive practices exist at the moment of departure and arrival (Lahire, 1998; Juan et al., 1997). No particular effort or preparation is undertaken to produce the act. It could be said that if mobility is movement, then transport is movement without a transfer, that is, individuals do not cross a "horizon of alterity", whereas transfer is the embracement of alterity.

The ensemble of these differentiated movements, where the individual changes between circulation and migration, where he experiences successively transport and transfer, could be termed "mobility", by including the values of mobility and immobility, and the representations and future movements (Lussault \& Stock, 2003; Kaufmann, 2002). We can agree with Remy (1996) that it is in contemporary, developed societies that mobility is valued, whereas in societies of old, immobility had been valued.

Thus, mobility is a "system" on different scales: on the scale of society, it ties together places, actors, the socio-economic and legal sphere and the infrastructure of means of transports, but also the social values of mobiliy (Bassand et al. 1985). However, we could also work with the notion of an "individual system of mobility" (Stock, 2001; 2003) where there are chains of movements, and interactions between, for example, tourist and business trips, migration and commuting (commuting as a substitute for migration), and so on. This leads to the observation of very differentiated systems of mobility, characterized by more or less mobility, but also of different moments during an individual's lifetime, characterized by moments of immobility and hyper-mobility.

People move a great deal and this raises the question of whether there is an adequate distinction between these movements: academics acknowledge this importance by changing their ways of approaching this phenomenon: everything is termed "mobility" nowadays, whereas everything has been termed "migration" until the 1990s. This does not shed much light on new forms of mobility and the difference between movements in an industrial society: the difficulties encountered with "international counterurbanization" (Buller \& Hoggart, 1994), soon termed "residential tourism" - which is a definitional absurdity because of the contradictory character of residence and movement - are examples of movements that come into being which we do not approach easily. If we recognize these problems, then the issue of classifying these practices arises. How can we draw adequate distinctions between the multiplicity of mobility practices, for example between tourist practices and leisure and business trips?

\section{Elements of a practice-based approach to mobility}

15 We approach mobility as a practice in order to acquire knowledge on mobility practices. More generally, the purpose is to understand and reconstruct what people do when associating practices and places. Thus, mobility is approached as a practice related to places. This approach is conceived in order to see practices not only as "social practices", but also as "geographical practices": they are always related to a place, and they take place. One can put forward the hypothesis that different practices 
express and require different places in order to be adequate. That means that each practice has its more or less appropriate place, whose qualities fit with the practices: for example, going on holiday in a tourist place rather than in an industrial city. This would be the "functional" aspect of practising places. However, there is also a "symbolic" aspect: a different degree of "involvement" - to cite the word used by Elias (1991) in describing a certain way of being - or "insideness" - to use the term employed by Relph (1976) to define one way of being with places.

How can we define "practice"? Some elements can help us to define the meaning of this important concept in the social sciences. Firstly, practice can be seen as what people do. In this, "practice" seems to be different from "behaviour" and "action". The theoretical perspective is not that of a "stimulus-response" conception, as in the case of a behavioural theory, where the man-environment relationship is a mechanic one. The distinction between "action" and "practice" is less clear. According to Max Weber (1980), "social action" is directed towards another individual. The term "practice" represents the process of "doing", which can be "pre-reflexive" (Bourdieu, 2000), rather than "action" which implies a certain form of rationality. Finally the question of practice has been developed in different fields of social and human sciences (economy, sociology, linguistics), and often been termed the "praxeological perspective" in economy (Mises, 1966). It develops an opposition between "representation" and "practice" and is thus termed the "non-representational approach" by Nigel Thrift (1996). Pierre Bourdieu $(1965,1982,2000)$ stressed the importance of this notion: his theory of practice attempts to express the tension between the individual and society by focusing on the habitus as a socially and individually informed disposition. Through regularity, the habitus is forged and used without reflexivity. Furthermore, Michel de Certeau (1990), by acknowledging the possibility of the individual not executing the action as is expected, is able to focus on the "ways of doing". Indeed, practice does not only represent "routinized" practices, such as are defined in "non-representational" approaches (Bourdieu, 1980; Thrift, 1996), which are carried out not only in the realm of daily but also non-daily practices, such as tourist practices, where distance and the constraint of self-control is less necessary (Elias \& Dunning, 1994).

17 Secondly, "practice" often refers to "social practice", but there are dimensions in practices other than the social one. Indeed, practice also has individual, temporal, spatial and symbolic dimensions. This had been developed by Norbert Elias (1996) who named this approach a "penta-dimensional model" of what human beings do. This means that practices are: 1) carried out by individuals and comprising individual variations of practices, the expression of Self within these practices, and the individual manifestation of these practices. Each individual has a personal history consisting in a past, present and future and based on emotions, reflections and so on; 2) socially informed: these are not only individual but also socially informed practices as individuals are embedded in social systems which facilitate their relationships with other individuals and social institutions; 3 ) of a temporal dimension: practices are carried out over time. They occur at a certain moment and for a certain length of time. This is socially and individually constructed time as the rules of working time determine certain obligations, and each individual makes his choices according to his experience; 4) of a spatial dimension: practices occur in places and are spatially differentiated. Certain places are devoted to certain practices and they constitute the backdrop for specific practices; 5) of a symbolic dimension: all practices have a specific 
significance, both for the individual and for society as a whole. Schütz (1974) shows that the object and intention of practices are directed towards society. Moreover, communication is made through symbols, language, images, signs.

From a geographical point of view, it is interesting to note that all practices are also "geographical practices", that is, practices with reference - explicit, chosen, prevalent, intentional or unintentional - to place, landscape, space, milieu and environment. The differentiated ways of using the "geographical dimension" in practices could therefore constitute an interesting research project. Geographical practice therefore implies the in situ character of places where experience, and thus the individual, play a certain role.

\section{Towards a comprehensive approach to mobility}

Individuals visit a place, but not only one place. This is why we speak of mobility. Indeed, we must take into account the ensemble of places visited, what could be termed, from the individual's point of view, an "individual system of mobility" (Stock, 2001). This would allow us to consider the structuring and possible substitution of different kinds of mobility: commuting as a substitute for migration in the case of a change in residence, links between business trips and tourist trips, etc. A comprehensive approach also attempts to embrace the different geographical practices which involve mobility.

What could this distinction between daily and non-daily practices and places mean? First, the difference between daily and non-daily practices lies in the more or less "routinized" or "deroutinized" character of practices, taking into account individual or emotional constraints (Elias \& Dunning, 1994). This distinction is integrated in a theory which considers that individuals find themselves in situations where autonomy and the opportunity to give free rein to their impulses are more or less allowed and possible. The self-constraint mode would constitute a feature of daily routinized practices, whereas leisure, on the contrary, would represent one of the possibilities of having less control, and thus pleasant emotions. "The unwinding of the theoretical thread which passes through the spectrum [of free time - M.S. \& Ph.D.] allows us to say that all leisure activities express a controlled release of emotional constraints [...] The categories comprising the spectrum of free time are generally distinguished by their degree of 'routinization' and 'deroutinization', or, in other words, by the difference in balance between these two tendencies in each category. Deroutinization goes beyond leisure activities but, here too, it is a question of balance" (Elias \& Dunning, 1994, p. 130). These practices of more or less "self-constraint" can be located in both daily and non-daily places. There are thus a multiplicity of practices which can be associated and carried out in more or less familiar places. This leads to the hypothesis that mobile individuals do not develop the same relationship with places, according to whether they are familiar or unfamiliar places (Stock, 2001). 
Table 1. The first distinction: daily place/non-daily place.

\begin{tabular}{lll}
\hline & Daily place & Non-daily place \\
\hline \multirow{2}{*}{ "De-routinized" practices (here: recreation) } & Leisure practices & Tourist practices \\
Routinized practices (here: work) & Commuting & Business trips, conferences etc. \\
\hline
\end{tabular}

SOURCE: MODIfIED FROM STOCK (2001), KNAFOU ET AL. (1997)

21 This double distinction is not sufficient to qualify the underpinnings of mobility practices. One way of doing so would be to distinguish both the practice and the context in which it is carried out, be it the quality of the place or in the temporal dimension, as approached by the individual. We can distinguish two first criteria that express the conditions of carrying out movement (table 2): 1) daily/non-daily and 2) choice/obligation. The first, as already established, means the break between routine and non-routine. Secondly, we could define obligation by the fact of not being able to refuse a practice without disrupting integration into social system(s). "Choice" is therefore "non-obligation", that is, the possibility of a greater autonomy in decisionmaking. The difference between a "business trip" and "tourist practices" lies primarily in the "choice" characteristic of the latter and the "obligation" characteristic of the former.

Table. 2. The second distinction: towards a "geographical code" of practices.

\begin{tabular}{lllll}
\hline Daily (D) & Choice (C) & Familiar (F) & Near (N) & "Non-exotic" (NE) \\
Non-daily (ND) & Obligation (O) & Unfamiliar (UF) & Far away (FA) & "Exotic" (E) \\
\hline
\end{tabular}

SOURCE: AUTHORS' CONCEPTION

The three other criteria express the qualities of the place with regard to relationship the individual establishes with the place at the moment of the practice. The aim is to approach the differential between place of departure (daily place) and place of arrival after the movement. This differential quality of place could be termed "diversity": When people move, they move to other places, societies, persons, "selves". The first question to ask concerns familiarity: is it a place that is regularly visited or not? Is the place familiar or unfamiliar? This is the distinction familiar/unfamiliar that focuses on the place that is more or less regularly visited. Nevertheless, diversity is not only a question of frequentation or non-frequentation, but also whether an individual has been introduced to the place by somebody or not. Indeed, the second distinction near/ far away focuses on this introduction by somebody (mediator) or not. This mediation between the individual and the place is a very important point that often conditions the possibility of access to a place. Some places like Le Touquet-Paris-Plage are only accessible to persons who possess a second home. To gain access to a place, individuals - if they do not possess the "keys" to it (in terms of cultural and economic capital, to choose Bourdieu's words) - need technologies of mediation. It is thus not a question of physical distance. Finally, the diversity of a place could be measured by certain "objective" elements with regard to the individual: the non-exotic/exotic focuses on differences in language, alphabet, habits, food, sexuality, gendering, and so on. 
These elements define a certain "geographical code" of practices (table 3) which corresponds to the combination of the different elements. Each practice - playing football, doing research, going on holiday, going to the cinema, and so on - can therefore be expressed by different geographical dimensions.

Table 3. Some examples of a geographical code of practices.

\begin{tabular}{llll}
\hline Example of practice & Geographical code & Abbreviation & Type of practice \\
\hline $\begin{array}{l}\text { A Londoner going on } \\
\text { holiday to Morocco }\end{array}$ & $\begin{array}{l}\text { Non-daily/Choice / } \\
\text { Unfamiliar/Far away/ } \\
\text { Exotic }\end{array}$ & ND-C-UF-FA-E & Tourist practice \\
$\begin{array}{l}\text { A Londoner going to } \\
\text { Marrakech for a conference }\end{array}$ & $\begin{array}{l}\text { Non-daily/Obligation/ } \\
\text { Unfamiliar/Far-away/ } \\
\text { Exotic }\end{array}$ & ND-O-UF-FA-E & Business trip \\
$\begin{array}{l}\text { A Brightonian going to work } \\
\text { in London }\end{array}$ & $\begin{array}{l}\text { Daily/Obligation/ } \\
\text { Familiar/Near/Non-Exotic }\end{array}$ & D/O/F/N/NE & Commuting \\
$\begin{array}{l}\text { A Londoner going to } \\
\text { Brighton \& Hove to stroll } \\
\text { on the beach }\end{array}$ & $\begin{array}{l}\text { Daily/Choice/Familiar/ } \\
\text { Near/Non-Exotic }\end{array}$ & D/C/F/N/NE & Leisure \\
\hline
\end{tabular}

SOURCE: AUTHORS' CONCEPTION

In this example, we can see that the first two elements are of great importance in the classification of practices. "Daily/Non-daily" and "Choice/obligation" determine the meaning of the practice and the other elements can vary. Indeed, what is interesting is that we can analyze different forms of mobility: for example, tourist mobility is defined by the first two elements, and the rest are variable: we can go to places which are familiar, or non-exotic/exotic, and so on. However, we can also see why there is so much confusion about the classification of practices, for example between tourist and business trips. Their geographical code is likely to be the same: the only element which changes is "choice" for tourist trips and "obligation" in the case of business trips.

\section{Questions and perspectives}

This "geographical code" leads to 64 possible combinations of the conditions of possibilities of practices and the qualities of a place. Some raise important questions for research on mobility: for example, is it possible to link a holiday trip to a familiar place (ND-C-F-FA-E)? If so, could this be defined "tourism"? More generally, these hypothetical insights raise two questions.

Firstly, how can we devise a "system of mobility" for individuals? Although it is important to scientifically conceive the ways of associating practices and places, it does not seem sufficient to remain on an individual level, but rather to conceive a "system of mobility" (Bassand and Schuler, 1980; Knafou, 1998) which acknowledges the links, on an aggregate level, of the flow. Furthermore, we can formulate the hypothesis that each individual constructs an "individual system of mobility" (Stock, 2001). 
Secondly, would the question of a "system of geographical practices" - with or without circulation or migration - not be one way to approach the concept of "dwelling" of human societies? The concept of dwelling could be used at least in three ways in a geographical approach to mobility. Classically, geography approaches dwelling as "human presence on Earth". This takes into account the indomitable human condition as individuals living on Earth, and the problems concerning their relationship with Nature. We could say that this is an cosmological approach which uses the concepts of "human ecology". Another approach seems possible, that of dwelling as the geographical reference of individuals. The difference with the former approach lies in the non-ecological issue: the question is not the relationship to "human milieus" - as Berque (2000) expresses it -, but the relationship to places and the layout of places. More or less familiar or unfamiliar places, emotional embedding into places, which in the end is one way of approaching the issue of "lived space", defined as the experience of space by individuals (Bollnow, 1963; Frémont, 1976; Relph, 1976). Finally, we could define dwelling, from the point of view of mobility, as the ensemble of geographical practices, including both the practice of visiting places and the relationship with places, imagined or practiced (Stock, 2001). In this perspective, we could conceive different "ways of living", more or less based on mobility or on a sedentary way of life (Stock, 2001).

To conclude, social scientists face a moment in the development of societies in which mobility increasingly constitutes the realization of social action and social relationships. Multiple places are visited with multiple intentions. Practices are not only carried out in one place, that of residence, but are also associated to many other places. Therefore, transfers must be made. It is this fact that expresses and can be defined mobility. The attempt to grasp some of the aspects of this association of practices/places, which may or may not include movement, was the purpose of this paper. We must now demonstrate and empirically prove these hypotheses.

\section{BIBLIOGRAPHY}

BAIROCH P. (1985), De Jéricho à Mexico, Paris, Gallimard.

BASSAND M. \& BRULHARDT M.-C. (1980), Mobilité spatiale, St. Saphorin, éd. Georgi.

BASSAND M., BRULHARDT M-C., HAINARD F. \& SCHULER M. (1985), Les Suisses entre la mobilité et la sédentarité, Lausanne, Presses Polytechniques Romandes.

BERQUE A. (1999), “Géogrammes. Pour une ontologie des faits géographiques”, L'Espace géographique, 28, 2, pp. 320-326.

BERQUE A. (2000), Écoumène. Introduction à l'étude des milieux humains. Paris, Belin (coll. Mappemonde).

BOLLNOW (1963), Der Mensch und der Raum, Stuttgart, Kohlhammer.

BOURDIEU P. (éd.) (1965), Un art moyen. Essai sur les usages sociaux de la photographie, Paris, Minuit. 
BOURDIEU P. (1980), Le sens pratique, Paris, Minuit.

BOURDIEU P. (1994), Raisons pratiques. Sur la théorie de l'action, Paris, Seuil.

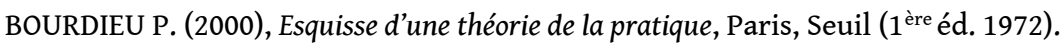

BRUNET R. (1990), "Le déchiffrement de l'espace ”, in BRUNET R., DOLLFUS O., Mondes nouveaux. Géographie universelle (Tome 1), Paris, Belin.

BRUNET R. (1993) “Article ‘Qualité”, in BRUNET R., FERRAS R., THÉRY H., Les mots de la géographie.

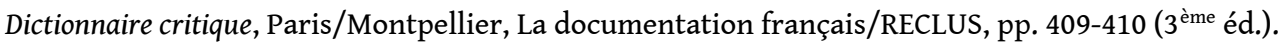

BULLER H. \& HOGGART K. (1994), International Counter-urbanization, British Migrants in Rural France, Avebury, Aldershot.

CERTEAU M. de (1990), L'invention du quotidien. 1. Arts de faire, Paris, Gallimard (1 ère éd. 1980).

CLAVAL P. (1981), La logique des villes. Essai d'urbanologie, Paris, LITEC.

COURGEAU D. (1988), Méthodes et mesures de la mobilité spatiale. Migrations internes, mobilité géographique, navettes, Paris, INED.

DUHAMEL Ph. (1997), Les résidents étrangers européens à Majorque (Baléares). Pour une analyse de la transformation des lieux touristiques, thèse de doctorat, Université Denis Diderot (Paris 7).

ELIAS N. (1995), "Sur le concept de vie quotidienne”, Cahiers internationaux de Sociologie, 99, pp. 237-246.

ELIAS N. (1996), Du temps, Paris, Fayard (1 ère éd. allemande 1984).

ELIAS N. \& DUNNING E. (1994), Sport et civilisation. La violence maîtrisée, Paris, Fayard (1 ère éd. anglaise 1986).

ÉQUIPE MIT (2002), Tourismes 1. Lieux communs, Paris, Belin (collection Mappemonde).

HELMFRID S. (1968), “Zur Geographie einer mobilen Gesellschaft. Gedanken zur Entwicklung in Schweden", Geographische Rundschau, 20, 12, pp. 445-451.

JUAN s., LARGO-POIRIER A., ORAIN H., POLTORAK J.-F. (1997), Les sentiers du quotidien. Rigidité, fluidité des espaces sociaux et trajets routiniers en ville, Paris, L'Harmattan.

KAUFMANN V. (2002), Re-thinking mobility: contemporary sociology, Avebury, Aldershot.

KNAFOU R. (1998), “Vers une géographie du rapport à l'Autre”, in KNAFOU R. (éd.), Les mobilités géographiques d'aujourd'hui, Paris, Belin, pp. 7-17.

KNAFOU R., BRUSTON M., DEPREST F., DUHAMEL PH., GAY J.-CH. \& SACAREAU I. (1997), “Une approche géographique du tourisme", L'Espace géographique, 26, 3, pp. 193-204.

LAHIRE B. (1998), L'homme pluriel. Les ressorts de l'action, Paris, Nathan.

LAZZAROTTI O. (2001), À propos de tourisme et patrimoine: les “raisons de l'Habiter", Diplôme d'habilitation à diriger des recherches sous la direction de R. KNAFOU, Université de Paris VII, $368 \mathrm{p}$.

LEFEBVRE H., 1999, La production de l'espace, Paris, Anthropos (1 ère éd. 1974).

LÉVY J. (1994), L'espace légitime. Sur la dimension géographique de la fonction politique, Paris, Presses de la Fondation Nationale des Sciences Politiques.

LÉVY J. (1999), Le tournant géographique, Paris, Belin (coll. Mappemonde). 
LUSSAULT M. (2000), “Action(s)!”, in LÉVY J. \& LUSSAULt M. (dir.), Logiques de l'espace, esprit des lieux. Géographies à Cerisy, Paris, Belin, pp. 11-36.

LUSSAULT M. \& STOCK M. (2003), “Mobilité”, in LÉVY J. \& LUSSAULT M. (dir.), Dictionnaire de la géographie et de l'espace des sociétés, Paris, Belin.

MERLEAU-PONTY M. (1945), Phénoménologie de la perception, Paris, Gallimard.

MISES L. von (1966), Human Action: A Treatise on Economics, Chicago, Henry Regnery (3 ${ }^{\mathrm{ème}}$ édition).

RELPH E. (1976), Place and Placelessness, Londres, Pion, 156 p.

RÉMY J. (1996), “Mobilités et ancrages: vers une autre définition de la ville”, in HIRSCHHORN M. \& BERTHELOT J.-M. (dir.), Mobilités et ancrages. Vers un nouveau mode de spatialisation?, Paris, L'Harmattan, pp. 135-153.

SACK R. D. (1980), Conceptions of Space in Social Thought. A Geographic Perspective, London, Macmillan (coll. Critical Human Geography).

SCHÜTZ A. (1974), Der sinnhafte Aufbau der sozialen Welt. Eine Einleitung in die verstehende Soziologie, Frankfurt, Suhrkamp (1 $1^{\text {ère }}$ éd. 1937).

SEAMON D. \& MUGERAUER R. (1989), Dwelling, place and environment. Towards a Phenomenology of Person and World, Dordrecht, Martinus Nijhoff.

STOCK M. (2001), Mobilités géographiques et pratiques des lieux. Étude théorico-empirique à travers deux lieux touristiques anciennement constitués: Brighton \& Hove (Royaume-Uni) et Garmisch-Partenkirchen (Allemagne), thèse de doctorat, Université Denis Diderot (Paris 7), $663 \mathrm{p}$.

THRIFT N. (1993), “For a new Regional Geography 3”, Progress in Human Geography, 17, 1, pp. 92-100.

THRIFT N. (1996), Spatial Formations, London, Sage.

WEBER M., 1980, Wirtschaft und Gesellschaft, Tübingen, Mohr (1 ère éd. 1921).

WERLEN B. (1997), Sozialgeographie alltäglicher Regionalisierungen. Globalisierung, Region und Regionalisierung (tome 2), Stuttgart, Franz Steiner Verlag.

WERLEN B. (1995), Sozialgeographie alltäglicher Regionalisierungen. Zur Ontologie von Gesellschaft und Raum (tome 1), Stuttgart, Franz Steiner Verlag.

ZELINSKY W. (1971), “The Hypothesis of the Mobility Transition”, Geographical Review, 61, 2, pp. 219-249.

\section{ABSTRACTS}

Geographical mobility increases in all domains and on all spatial scales: tourism practices, migrations, business trips, commuting, leisure circulation and so on. It has become an important phenomenon for research in the social sciences. Nevertheless, attempts at conceptualisation are still heavily limited because mobility is rarely viewed as a system in which the ensemble of movements are linked. It has become necessary to adopt a comprehensive approach towards mobility that focuses on the various practices employed and that targets the different types of mobility. Indeed, the following questions are raised: how should the numerous circulations and migrations be conceived and interpreted? How can the different population movements be classified? In this paper, we will attempt to adopt an original approach: to classify different practices of mobility using a "geographical code of practice". This code takes into account the 
conditions in which movements occur and the characteristics of the geographical sites involved. In this way, we hope to contribute to a theory of geographical mobility which leads to a new appreciation of the ways individuals dwell in geographical places.

La mobilité géographique s'accroît dans tous les domaines et à toutes les échelles spatiales: déplacements touristiques, migrations, voyages d'affaires, circulations domicile-travail, circulations de loisir etc. Elle est devenue un phénomène important pour les chercheurs en sciences sociales. Cependant, les tentatives de conceptualisation restent éparpillées du fait que l'on n'aborde que rarement la mobilité comme un système dans lequel l'ensemble des mouvements serait lié. Il est devenu nécessaire de tenter une approche globale de la mobilité, qui part des différentes pratiques de mobilité effectuées et qui arriverait à dégager différents types de mobilités. En effet, il se pose la question suivante: comment ordonner et interpréter les nombreuses circulations et migrations? Comment arriver à une classification des différents mouvements de population? On tentera ici une approche originale: classer les différentes pratiques de mobilité pour dégager les types de mobilité à l'aide d'un "code géographique des mobilités". Ce code tient compte à la fois de la qualité des lieux pratiqués (lieu du quotidien, lieu du hors-quotidien) ainsi que du rapport au lieu qui est impliqué dans la mobilité effectuée (lieu familier, étranger, exotique etc.). C'est ainsi que nous espérons contribuer à une théorie de la mobilité géographique qui ouvre vers une nouvelle appréciation de la manière dont les hommes habitent les lieux géographiques.

\section{INDEX}

Mots-clés: mobilité, pratiques, habiter, migration, circulation, transport

Keywords: mobility, practice, dwelling, migration, circulation, transport

\section{AUTHORS}

\section{MATHIS STOCK}

University of Reims Champagne-Ardenne, Équipe MIT, mathis.stock@wanadoo.fr

\section{PHILIPPE DUHAMEL}

University Denis-Diderot (Paris 7), Équipe MIT, ph.duhamel@wanadoo.fr 